\title{
"No Med School!" Black Resistance to The New Jersey College of Medicine and Dentistry (NJCMD) Urban Renewal Proposal, Between 1960 and 1970
}

\author{
Edad Mercier ${ }^{1}$ \\ St. John's College of Liberal Arts and Sciences at St. John's University, United States
}

\begin{abstract}
This article is a historiographical study of urban renewal in Newark, New Jersey. The paper offers a cross-sectional view of policymaking and appropriation at the federal and local levels, which is critical when analyzing the delimitations of ethnic coalition building. The article centers on a typological study of Black resistance to the New Jersey College of Medicine and Dentistry (NJCMD) construction project that was slated to commence around 1965-1966. NJCMD, renamed the University of Medicine and Dentistry, New Jersey (UMDNJ) in 1981, was initially proposed as a revitalization project that would stymie urban decay in Newark. However, the project proposal would also displace close to 22,000 people in the Central Ward - a predominately poor, majority Black section of Newark. Using social movement scholarship, specifically the literature on resource mobilization during the mid-twentieth century Civil Rights Movement, this article examines the distinct ways that Black residents of Newark responded to the NJCMD project. The response involved community board meetings, rallies, and surveys that ultimately led to significant overhauls of NJCMD's initial design. Black resistance to NJCMD also culminated in the 1970 election of Kenneth Gibson, Newark's first Black mayor. Key concepts such as "collective action framing" and "frame diffusion" inform this study of grassroots mobilization and community resistance. Also included in this work is an exploration of Black Power politics, its key figures in Newark, and the impact that such solidarity movements had on municipal politics. A thorough analysis of "pressure politics" and "protest politics" in the public sphere will also shed light on how racial exclusion frames elections and electorates.
\end{abstract}

Keywords: grassroots protest, marginalization, Black, urban renewal, Newark.

\section{Introduction}

After Dr. Martin Luther King, Jr.'s assassination in April 1968, Reverend Ralph Abernathy led protestors into Washington D.C. in May 1968 in continuation of Dr. King's Poor People's Campaign (Abernathy, 1989; Jackson, 2007). In total, 6,312 people gathered around the National Mall, creating a settlement called Resurrection City. Rev. Abernathy passed out handbills to "city" residents that communicated the movement's stance: "What will the Poor People's Campaign do in Washington?...We will build powerful nonviolent demonstrations on the issues of jobs... housing, human rights....We must make the government face up to poverty and racism" (Meier, 1973, pp. 5-7).

\footnotetext{
${ }^{1}$ Author e-mail: edad.mercier20@my.stjohns.edu
} 
When federal authorities removed the homes of Resurrection City residents from the National Mall in June 1968, the movement for participatory governance and racial inclusion appeared to end. Yet, several hundred miles away in Newark, New Jersey, residents of the city were engaged in a similar battle to protect their homes and livelihoods from destruction. Black resident opposition to the construction of the New Jersey College of Medicine and Dentistry (NJCMD) between 1960 and 1970 tackled the same issues that "residents" of the Resurrection City encampment had raised: issues like fair citizen participation in local governance; good jobs; housing and integration; and antipoverty programs.

Black Newarkers mounted a collective resistance to what they perceived were unjust urban renewal practices. The resistance to NJCMD lasted several years and bridged different government agendas to produce an "urban democratic grassroots coalition." examines how an "unintentional" urban democratic grassroots coalition, forged from divergent community responses and needs to urban renewal in Newark, transformed the spatial and political reality of mid-twentieth century Newark, by spurring community-led movements founded on the demand for racial inclusion in public policy. This cultural-historical study is based on a critical analysis of collective action and social movement theories, and federal, state, and city urban redevelopment policies. The article makes a significant contribution to political and historical research on the application and interpretation of city planning policies in the Northeast during the 1960s - while interrogating the limits of decentralized, grassroots activism and protest as a national approach to tackling racism in urban renewal programs.

\section{Urban Renewal in the United States}

As post-war industry in the United States declined in the 1940s, major cities in the Northeast and Midwest faced considerable losses in manufacturing employment making urban decay a national issue. To combat urban decay, President Truman (1949) expanded on FDR's New Deal (1933) with the Fair Deal (1949). As part of the Fair Deal, President Truman outlined plans for greater federal oversight on state and municipal budgets and programming to improve America's cities in a process called urban renewal. At the federal level, urban renewal was framed as a battle against urban decay through targeted federal spending on local programs to clear out slums.

Title I of the Housing Act of 1949 passed under the Fair Deal called "for slum clearance programs associated with urban renewal projects in American cities" (US CODE: Title 42,1441. Congressional Declaration of National Housing Policy) and created the Division of Slum Clearance and Urban Redevelopment. In Title I of the Housing Act, the federal government established the "write down." With the write down, the federal government covered two-thirds of the funding required to clear out slum areas, while local governments funded one-third of the cost (US CODE: Title 42,1441) (Congressional Declaration of National Housing Policy, 1949). Although it would take decades for blighted neighborhoods to undergo serious, structural improvements, the "write down" helped paved the way for a new era of cooperative policy making between federal, state, and city officials (Teaford, 1986). Rapid shifts in the demographics of America's cities between the early to mid-twentieth century also compelled urban redevelopment reforms at the federal level.

Alongside immigration from Eastern Europe to the United States at the start of the 1900s, the largest internal migration ever recorded in American history was also underway. During the first and second waves of the Great Migration between 1916 and 1970, almost six million Black people moved from the rural South to urban parts of the North, and settled in

\footnotetext{
${ }^{2}$ Following on the work of Manuel Castells (1983) and Robert Putnam (2001) an "urban democratic grassroots coalition" is what I call a coalition that subscribes to the philosophy behind traditional democratic systems for its internal organization while specifically leveraging or counter posing the community-based social or physical assets of a particular group or groups of people, regardless of clashes in perspective or outlook.
} 
cities like Chicago, Norfolk, Philadelphia, and New York (Trotter, 2002). In Hartford alone, between 1920 and 1930, the population of Blacks more than doubled from $20 \%$ to $78.8 \%$ during the Great Migration: "From just more than 20 percent of the residents in 1920, by 1930, 78.8 percent of the residents on Bellevue were African Americans" (Schlichting, Tuckel, \& Maisel, 2015, p. 308). The Great Migration of Blacks to the North was mainly driven by a desire to find better jobs and housing and to escape the rise of Jim Crow, lynching, and the Nadir of American race relations in the South (Gates, Jr., 2019). But with surmounting tensions from white racism that forced Blacks into dilapidated housing and some of the worst jobs in the Northeast's violent urban ghettos, the move up North was no panacea. It was only in 1963, following President John F. Kennedy's assassination, under President Lyndon B. Johnson's landmark Great Society, War on Poverty initiative, that federal policies would begin to aggressively examine the effects of racial exclusion and violence on America's major metropolises.

President Johnson's Great Society adopted Truman-era "cooperative federalism" from the Fair Deal to form the War on Poverty. Cooperative federalism, or joint cooperation between state and federal policymakers on the enforcement of laws and provisions (Cruden, 2016; DeCaro, Chaffin, Schlager, Garmestani, \& Ruhl, 2017; Greve, 2020), encouraged the creation of new public programs under the War on Poverty, while also articulating an urgent response to the racial anguish experienced by Blacks in the United States. During the War on Poverty in 1967, President Johnson established the Kerner Commission to determine the causes and consequences of race riots. The Report of the National Advisory Commission on Civil Disorders, or the Kerner Report, published by the commission on February 29, 1968, was a warning that if federal, state, and municipal governments did not work together to improve socioeconomic opportunities for all citizens, regardless of race, America's cities would rot away along with the American Dream (Farley, 2018; Gooden \& Myers, 2018). The Model Cities program (1966) — a series of legislative policies aimed at restructuring municipal leadership and local spending - eventually became the main vehicle for implementing most of the recommendations from the Kerner Report. The Model Cities program created the Department of Housing and Urban Development (HUD). HUD disbursed federal funds to cities on a caseby-case basis for urban redevelopment. City redevelopment proposals to HUD could include requests for funds to build affordable housing, public health programs, and civic centers. Detroit, Newark and Camden were some of the first recipients of funding for city rehabilitation initiatives under the Model Cities program.

\section{NJCMD and the Model Cities Program}

When NJCMD trustees left Jersey City in 1966 in search of areas that would suit the medical school's expansion, the state of New Jersey originally proposed a suburb called Madison for the new college site. Newark city officials quickly offered 40 acres to contractors, making their offer significantly more competitive than the Madison proposal. So in 1966, Chairman of the Newark Central Planning Board, George Smith, announced that Newark would be the tentative site for NJCMD under the following conditions: "(1) assurance of the availability of 50 acres clear and free of all houses by March 1, 1968, and (2) assurance of an additional 100 acres, irrevocably committed for future college use" (Williams, 1968, p. 6).

Newark Mayor Hugh Addonizio's 1967 Model Cities Report was part of a larger request to the Model Cities program for $\$ 198,000$ to assist with development projects in Newark, like NJCMD. In the 1967 report, Addonizio outlined the dire situation in the city: "Among major American cities, Newark and its citizens face the highest percentage of substandard housing, the most crime per 100,000 of population, the heaviest per capita tax burden, [and] the sharpest shifts in population" (Addonizio, 1967, p. 5). Addonizio predicted that NJCMD campus 
expansion would drastically change the entire Northeast Corridor by attracting new talent and a mix of private-public investments:

That single event, the location of a major medical college in the heart of a central slum area, should prove as significant to Newark as the city's construction, long before the Port of Authority, of an airport and deep water channel. Its region-shaping force is central to the future of Newark and the Model Neighborhood Area. (Addonizio, 1967, p. 16)

The problem with Mayor Addonizio's 1967 Model Cities Report was that his administration committed to providing more than 100 acres for NJCMD expansion, primarily in the Central Ward. Construction in the Central Ward would displace close to 22,000 people, majority Black and poor, with nowhere else to go:

Addonizio initially offered the school two hundred acres of land in the Central Ward, which would have displaced 22,000 mostly black people. Black folks and our supporters said 'Hell no,' and flocked to a series of meetings at city hall before the Planning Board. (Williams, 2014, p. 148)

The social costs of displacing up to 22,000 people undermined the viability of the NJCMD expansion proposal in Addonizio's1967 Model Cities Report and added to the growing tide of Black frustration and indignation from decades of social exclusion, segregated housing, and excessive policing. Dr. Stanley S. Bergen, an NJCMD trustee and second president of the college later remarked that "the [Black community] had been neglected in ... significant policy decisions... [representing] a serious breach of trust by both the mayor and the negotiators representing the State of New Jersey" (Cunningham \& Hill, 1988, p. 316).

\section{Ghettoization and the Urban Polity}

In Newark: A History of Race, Rights, and Riots in America (2007) historian Kevin Mumford argued that Black residents were frequently unprepared to (re)claim their share in the context of massive economic and social change that urban renewal projects brought to major cities, because of prejudice, urban poverty, and racism. Scholarship on the psychology of the "ghetto condition" further underpins the idea of an underclass resigned to its self-fulfilling prophecy of economic disenfranchisement and civic invisibility. Studies from 1980 to 2014 show that Black residential segregation is correlated with high concentrated poverty rates due to 'fragile families,' negative kin and non-kin networks, crime, and structural racism (Massey \& Denton, 1993; Wilson, 2012). Iceland and Hernandez (2017) for example note that across all cross-sectional models between 1980 and 2014 "the most consistent predictors of black concentrated poverty are income segregation and overall poverty." These findings align with conclusions from Hofferth and Goldscheider (2010) that 'fragile families' and weak social capital in the Black community are strongly associated with socioeconomic disadvantage.

In his seminal work Dark Ghetto: Dilemmas of Social Power (1965), Dr. Kenneth Clark was one of the first Black psychologists to assert that a Black ghetto underclass existed in American cities, as the result of urban violence, physical and psychosocial trauma. Clark wrote that "when the poor are Negro, as they increasingly are in American cities, a double trauma exists - rejection based on class and race...The dark ghettos are social, political, educational, and-above all-economic colonies... [The Negro] is in danger of becoming a permanent economic proletariat" (Clark, 1965, p. 34). Although the Central Ward was "ghettoized" by 
what Clark might assess was the result of "rejection based on class and race" (Clark, 1965, p. 34)-ghettoization did not entirely explain why Black people were completely left out of planning decisions in Newark.

By the early 1960s, there were Black officials in Newark like councilman Irvine Turner, and state legislator George Richardson D-Essex, who were vocal and visible. However, their influence over local policy making was greatly limited. Newark activist Tom Hayden, a key figure in Newark politics in the late 1950s and 1960s, argued that tokenism and political patronage were likely the main reasons for racial exclusion in legislative decision making, especially in major Northern cities: "Black people occupied only token positions in city administrative and political life, and these positions were more dependent on the mayor's will than the support of ghetto voters. Negro leaders blamed the government and social agencies for fostering and neglecting problems, using federal funds to bolster their patronage rolls rather than meeting the crisis of the city" (Hayden, 1967, p. 7).

Black tokenism and white patronage contributed to the rise of ethnic machine politics and politicians, who almost exclusively focused on the demands of the largely working-class Jewish, Italian, and Irish immigrant neighborhoods of Newark in the North Ward (Casciano, 2009). Challenging decades-old political and social customs would require a new brand of activism that would not only motivate but also educate the Black masses in Newark about their civil, economic, and political rights - because, though a project like NJCMD campus expansion was not necessarily "for" or "against" any particular racial or ethnic group in Newark, the path to its implementation meant ignoring and displacing thousands of Black residents.

\section{"Protest Politics" and the Roots of Black Resistance to NJCMD}

Leaning on collective action strategies from the Civil Rights Movement, Robert Curvin, Junius Williams, and Tom Hayden were among the first grassroots activists in Newark to build public outreach and awareness campaigns from the ground up to mobilize Black residents of the Central Ward against the NJCMD project. According to Benford and Snow, social movement actors will strategically borrow from other "collective action frames" if the "conditions of similarity or compatibility between transmitters and potential adaptors are...in need of construction" (Benford \& Snow, 2000, p. 627). When Hayden formed branches of Students for a Democratic Society (SDS)/Economic Research and Action Project (ERAP) in Newark, he employed many of the organizing strategies from the Civil Rights Movement to help Newark's Black residents join SDS/ERAP and protest NJCMD. Mobilization strategies from the 1960s Freedom Rides, such as training workshops and rallies, for instance, influenced the public outreach and protest methods of SDS/ERAP in Newark. National leadership initially denounced Freedom Riders, led by the Congress of Racial Equality (CORE), as provocateurs. But in September 1961, after substantial local and international media attention, the Interstate Commerce Commission (ICC) began desegregating buses (Arsenault, 2005; National Public Radio [NPR], n.d.) The national success of the Freedom Rides energized other activists like Robert Curvin, who in 1963 set up a branch of CORE in Newark, to join the work of SDS/ERAP in mobilizing disenfranchised Blacks.

The Barringer High School protest in 1963 was perhaps the earliest example of strategic borrowing in community protest during the civil rights era in Newark. On July 3, 1963, more than 200 demonstrators gathered in front of the construction site for the Barringer High School in Newark ("Workers, Pickets Clash at Barringer Project," 1963; "Racial Job Clash Erupts in Jersey," 1963). Headed by the Newark Coordinating Committee (NCC) and state legislator Richardson, demonstrators were protesting racial discrimination in hiring at the construction site ("Workers, Pickets Clash at Barringer Project," 1963). The NCC, a coalition of different 
civil rights groups in Newark including SDS/ERAP and CORE, argued that the school construction project should be more integrated with Blacks and Puerto Ricans. The protests erupted into a five-minute brawl, where even Richardson had to be "bodily lifted from the street by police" according to a special report from the Newark Evening News ("Workers, Pickets Clash at Barringer Project," 1963).

The Barringer protests also fueled discord among the few Black leaders in Newark, as some thought the protests were too hasty. Councilman Irvine Turner openly criticized the Barringer School demonstration: "Irvine Turner, the only African-American on the Newark City Council, publicly opposed the pickets and criticized Curvin specifically," and "at one "very tense' meeting Curvin was removed at the insistence of an NAACP leader" (Rabig, 2007, p. 35). Under pressure, Addonizio summoned the Newark Human Rights Commission to investigate the $\$ 6,500,000$ school building project. By the time plans for NJCMD unfolded in 1965-1966 though, Newark's grassroots activists realized that they would need more than one or two Black legislators and picket lines to disrupt the major proposal.

\section{"No Med School!"}

During a tense community meeting, state legislator Richardson returned to the public stage in Newark - but this time to outline the negative impact that the NJCMD campus expansion plan would have on the Black community. As Richardson spoke, other voices filled the air-and the words coming from the crowd became more audible: "No Med School!" (Tibaldo-Bongiorno, 2007).

Black resistance to NJCMD expansion was not solely opposition to the entire construction proposal. Central Ward resident surveys conducted by the United Community Corporation (UCC) in 1965 showed that residents wanted to amend certain aspects of the proposal: "Although 76 percent of Central Ward residents supported building the new medical school somewhere in Newark...only 46 percent favored the school if they would be forced to relocate .... and 77 percent of ...tenants...said they [would] move if they [were] given enough to pay for the cost of moving" (Mumford, 2007, p. 113). Seeing the potential benefits of NJCMD campus expansion, these surveys revealed that Black residents of the Central Ward sought fair compensation and leadership in the project.

Following the release of the surveys, SDS/ERAP and Newark-CORE used a combination of grassroots campaigning methods to ensure NJCMD expansion would reflect the concerns of Black residents. Organizing strategies included door-to-door campaigns, free legal workshops for Black Newarkers, free community education centers, picketing, and boycotts. Yale Law School student Junius Williams emerged as the most visible leader in NJCMD protests for racial inclusion when he joined the local organizing efforts of CORE and SDS/ERAP in 1965. With the crucial 1970 Newark mayoral elections looming ahead, the NJCMD plan would severely limit the chances of a Black mayor-let alone a racially inclusive mayoral race, because almost the entire Black voting bloc in Newark would be displaced were NJCMD construction to move forward. Williams thus proposed reframing resident opposition to NJCMD expansion as a campaign against unjust relocation and sociopolitical repression.

\section{"Pressure Politics" and Altering the NJCMD Plan}

"Pressure politics" and changes to the NJCMD plan meant taking a legal, political, and economic stance on just land use in the Black community. Williams co-founded the Newark Area Planning Association (NAPA) with the goal of exposing racial discrimination in Newark city management, planning operations and procedures. NAPA operated off two essential rules: "get the right information at the right time...expose violations of the formal rules of the game" (Williams, 1968, p. 42). NAPA aimed to reveal NHA bias in land use and population surveys 
by training Newark's Black residents to: "(a) find the people in City Hall who knew about the surveys taken by the City; (b) find technicians from within the academic world who could tell [activists] how to spot defects in the questionnaires used in the survey; and (c) find people who knew about surveys showing qualified approval of the medical school" (Williams, 1968, p. 50). Through NAPA, Williams also recruited the aid of Newark VISTA Legal Associates and volunteers from the Committee Against Negro and Puerto Rican Removal led by Mrs. Louise Epperson to support education workshops for Black residents. With pressure from NAPA, VISTA, CORE, SDS/ERAP, and the Committee Against Negro and Puerto Rican Removal, HUD was finally forced to reexamine the 1966 Relocation Report on NJCMD from Newark planning officials.

Upon further review, HUD officials concluded that "(1) the size of the school was questionable (2) There was no minority group report present pursuant to Section 10-1 of the Urban Renewal Manual, (3) the 1966 Relocation Report was internally contradictory and omitted certain information" (Williams, 1968, p. 67). By attacking the overall integrity and viability of the NJCMD expansion plan, Williams, Hayden, and other activists succeeded in showing that the NHA was an unreliable city partner and that community residents should play a bigger role in planning decisions. The 1967 rebellion which coincided with HUD's concerns about the suitability of the NJCMD expansion plan accelerated negotiations to alter the project.

\section{“Black Power,” Rebellion '67 and Negotiating NJCMD Expansion}

Police brutality, deplorable housing conditions, and a poor educational system were some of the precipitating factors leading up to the Newark 1967 rebellion. The 1967 rebellion in Newark began on July $12^{\text {th }}$ and lasted for six days. The violence purportedly began when two white Newark police officers stopped a Black taxi driver named John Smith in the Central Ward and charged him with assault and battery. Bystanders declared, however, that the officers brutally beat Smith. In the five days that followed, people took to the streets in violent protest of several issues, including police brutality and the NJCMD proposal. Twenty-six bodies were counted in the aftermath of the riot - "between July 12 and 17, 1967, twenty-four African Americans and two whites died in law enforcement maneuvers, from stray bullets and motor vehicle accidents, in lethal skirmishes of defiance and retribution" (Mumford, 2007, p. 125). When the last National Guardsman filed out of Newark and the news cameras were packed away, a new feeling settled in the streets of Newark: the rhetoric and stance of Black Power.

The Black Power movement was largely based on the teachings and work of Black nationalist civil rights activist, Minister Malcolm X (el-Hajj Malik el-Shabazz), who was assassinated in 1965 ("Malcolm X: From Nation of Islam to Black Power Movement," 2018). The term "Black Power," which expresses the political ideologies of a movement for Black solidarity against racist institutions, was popularized in the late 1960s and 1970s with the publication of Black Power: The Politics of Liberation in America (1967) by activists Stokely Carmichael and Charles V. Hamilton. The Black Panther Party (BPP), strongly associated with Black Power activism, was an anti-racist, anti-fascist, neo-Marxist political party founded by Bobby Seale and Huey P. Newton around 1966 (dissolved, 1982). The development of Black Power activism marked much of the unrest in Newark surrounding state violence and sociopolitical exclusion in the late 1960s and early 1970s. Two weeks after the 1967 rebellion in Newark, a Black Power Conference was held. A Newsweek article described the diverse assembly of people, from Ron Karenga ${ }^{3}$ in his "orange on pale green kimono-like shirts" to

\footnotetext{
${ }^{3}$ Ron Karenga, or Maulana Karenga (born Ronald McKinley Everett), was active in the Black Power movement. He is perhaps best known for developing the holiday Kwanzaa, first celebrated in December 1966. Karenga was
} 
those who "looked drearily conservative in business suits" (Tuttle, 2009, p. 172). Although conference attendees differed on strategies for uplifting Black people, the presence of a new, Black identity in Newark was palpable.

Black cultural nationalist Amiri Baraka, who was involved in community organizing in Newark, also became more prominent in the aftermath of the 1967 rebellion. According to Baraka, Blacks felt a pressing sense of urgency and need for self-determination that was tied, but not exclusive to a full expression of a Black identity. Building off the energy from the Black Power conference in 1967, Baraka began hosting meetings with Black residents of Newark. The male attendees of these meetings called themselves the United Brothers, and the female attendees called themselves the United Sisters. By June 1968, the United Brothers sponsored the first Black Political Convention in Newark nominating candidates to city council: "the candidates on the United Brothers slate received the overwhelming majority of those votes in predominately black wards that were cast for city council candidates" (Watts, 2001, pp. 359). Speaking on the convention, Baraka declared, "we've come to conclude that the city is ours anyway, that we can take it with ballots" (Watts, 2001, p. 357). Baraka's cultural activism and a renewed sense of Black solidarity on issues like voting strengthened resident opposition to NJCMD. NJCMD staff also felt the weight of public outrage against the NJCMD project and in a winter 1967 meeting, the initial NJCMD expansion plan received only two votes from faculty at the medical school (Cunningham \& Hill, 1988, p. 332).

When Junius Williams returned to Law School in the fall of 1967, he reached out to several architects to design an alternate plan for NJCMD. The team of architects was the Architects' Renewal Committee of Harlem (ARCH), which joined VISTA's efforts to build the legal case for an alternate design for NJCMD that would take up only 19 acres (Interview of Junius Williams on the UMDNJ Fight) (Lituchy, 2007b). This alternate plan became the rallying cry for Central Ward residents because it was a plan for community control and selfdetermination that mirrored much of what Black Power activists were demanding at state, city, and federal levels.

\section{More Power to the People}

In February 1968, at the request of HUD officials, Junius Williams, Louis Danzig, director of the NHA, Dr. Robert Cadmus, the president of NJCMD, Donald Malafronte, chief of staff under Mayor Addonizio, and several other legislative and community stakeholders formed a nine-person committee to reach a binding compromise on NJCMD, called the Newark Agreements. The Newark Agreements, officially released in March 1968, comprised six sections: "I. Acreage," "II. Health Services, Employment, and Training," "III. Relocation," "IV. Medical College Construction," "V. Model Cities," and "VI. Housing Construction" (Newark Agreements, 1968).

Under Section I of the Newark Agreements, NJCMD trustees, the NHA, and Newark planners agreed to decrease the acreage originally allotted for NJCMD construction from 167 to 57.9 acres. Section II specified that NJCMD would devote a "minimum of $\$ 2.5$ million to the...improvement of health services" and training facilities at Newark City Hospital, plus a community health council. Section III ensured that families would not be relocated until adequate living alternatives were secured-and for the families unable to move, a rent supplement would be provided. A HUD review board was also created to hear and address complaints of relocated persons. Section IV authorized "minority group employment on the medical construction site" in hiring agreements. Section V affirmed that the Model Cities Program would "strictly [adhere] to ...the Newark City Demonstration Agency." Section VI designated a "Community Housing Council" of community members, HUD and NHA officials.

influential in the modern development of Black cultural nationalism, which is explored in his influential piece Kawaida. 
The Community Housing Council was tasked with designing a housing program "to produce sufficient housing to meet the demand created by project dislocation" (Newark Agreements, 1968).

The Newark Agreements were a victory of epic proportions for Black residents of Newark. Mobilization efforts in the Black community produced a new urban democracy, where decisions once made in the private offices of N.J. state leaders, were now subject to public deliberation, revision, and open criticism in community board meeting rooms across Newark. Comprehensive revisions to the NJCMD proposal and the subsequent 1970 election of Kenneth Gibson, Newark's first Black mayor, gave the city's now largely Black majority hope that the outcomes of grassroots resistance to NJCMD would feed into all other public policy decisions.

\section{Electing Kenneth Gibson, Newark's First Black Mayor}

Mayor Kenneth Gibson, D-Newark, like his contemporaries Mayor Coleman Young, D-Detroit (1974) and Mayor Tom Bradley, D-Los Angeles (1973) ran a highly politicized and racialized campaign for office that channeled the language, style, and activism of the Black Power movement into a successful party platform (Thompson, 2006). NAPA, CORE, SDS/ERAP were all involved in the Gibson campaign and adapted Black Power movement organizing tactics. Strategies such as handbills, buttons, "personal contact and citizen involvement through walking tours, neighborhood coffee hours, motorcades, and rallies in black areas" (Gelb, 1974, p. 523) were used to energize Black people and shift attention away from angry white voters. Gibson also reached out to small communities and presented himself as the people's candidate, a reformer. Gibson later recalled, "I ran a civil rights type of campaign" (Mumford, 2007, p. 198).

The incumbent, Mayor Addonizio, entered the 1970 mayoral elections disgraced. One campaign poster for Gibson accused Addonizio of neglecting Newark, and even hinted that Addonizio was involved in drug trafficking (Gibson Civic Association, 1970). When formal charges of corruption were brought up against Addonizio in the spring of 1970, Gibson's campaign ads seemed to validate the growing public sentiment that Addonizio was unfit for office. On April 21, 1970, after several grand jury hearings, Mayor Addonizio and fourteen codefendants were charged with operating a "pay-off system" in an extortion scheme worth more than \$1 million, involving Constrad Incorporated, an engineering firm (Cunningham \& Hill, 1988, p. 334). Radical members of Addonizio's white constituency were also not pleased with Addonizio's handling of racial integration in Newark's neighborhoods.

Anthony Imperiale was the most visible figure of white backlash to housing integration in Newark. He was also the spokesman for white residents, who believed that Mayor Addonizio's administration took a relaxed stance on protecting white residents from Black "encroachment." Imperiale formed the North Ward First Aid Squad to "ensure the safety" of white residents in predominantly Black neighborhoods. To court white voters, Addonizio adjusted his mayoral campaign to fit the "race baiting" tactics of Imperiale (Halbfinger, 1999), but Gibson's reputation as the experienced, practical, civil engineer from Newark secured his image as the better candidate. By the end of 1970, Addonizio, embroiled in scandals and lawsuits, could no longer hold on to the trust or money of his loyal backers in city and federal government.

On May 12, 1970, Gibson won 43 percent of the city's votes. Because he did not receive more than fifty percent of the vote, Gibson was forced into a runoff. In the June runoff, Gibson won 55,097 votes, and Addonizio won 43,086 votes. On the day of Gibson's official victory, thousands of Gibson supporters rejoiced outside of City Hall (Cunningham \& Hill, 1988, p. 335). When celebrations ended, Gibson went to work on developing proposals that would bring 
much needed private and public investments to revive Newark's depressed economy following the 1967 rebellion. In an essay entitled "A Case for Equity in Federal-Local Relations in Urban Policy Development," Gibson wrote that certain income-generating reforms were needed in the revitalization of cities like Newark: "infusing new capital into the central cities for urban development...adjusting the tax structure at all levels to make the cost of living and doing business in the cities more attractive... [and] getting local governments, especially depressed central cities, back into the capital market are...essential ...in restoring urban America to financial health" (Gibson, 1978, p. 142). Gibson assured Black voters that his proposals for capital reform in Newark would involve community activists. Not to worry, the public could "participate in hearings on the use of revenue sharing funds, thereby participating more in the operation of municipal government itself" (Gibson, 1978, p. 138).

For Gibson, community participation in city planning could be appreciated in many forms, like attending city hearings, but expediency and efficiency were priority. Consequently, when Gibson was handed the details of the Gateway Urban Renewal Project in Newark, a massive center for retail stores and offices-backed by large financial corporations - he immediately fast-tracked its approval, deciding that any delays to the project's rapid implementation would be irresponsible, especially given the fiscal and social crisis in Newark.

\section{The Gateway Urban Renewal Project}

The Gateway Urban Renewal project defined Gibson's time as Mayor of Newark. The NHA first proposed the Gateway Urban Renewal project for downtown Newark in 1959. Its construction was divided into two main phases. The first phase was Gateway One, a concourse, and a shopping mall. The second phase was Gateway Two, the future home of the Western Electric Company. The Gateway complex would be built between Penn Station and Mulberry Street, and North to South between Raymond Boulevard and Market Street, bordering the Central Ward. Unlike the NJCMD campus expansion proposal, the Gateway Urban Renewal project was not zoned for a residential area-only light industrial operators were displaced. However, Black residents in the Central Ward insisted that they should be included in negotiations for the Gateway complex.

Recalling the grassroots movement against the NJCMD project, Black residents protested the Gateway project and demanded community input. Amiri Baraka maintained that large corporations backing the Gateway project, like Prudential Financial, were only interested in producing a profit. These companies would not invest in the Black community located near the proposed massive complex. Nevertheless, the Gateway project sped forward-Gateway One was completed in 1971 and Gateway Two was completed in 1972. Gateway Three and Gateway Four were completed in 1985 and 1988, respectively. A furious Baraka later called Gibson a "neocolonialist" (Dolan, n.d.), who profited from large corporations and ignored the Black voters who got him elected.

When Black activists secured Gibson's mayoral victory in 1970, they hoped that he would rethink Gateway construction, given the visibility and influence of Black Power activists and grassroots organizers throughout his campaign ("Ken Gibson with Supporters," 1970). Even more frustrating for Black activists in Newark was that while Gibson actively supported the Gateway project, funded by corporate developers not even headquartered in New Jersey, he disregarded local community-driven urban redevelopment proposals. In September 1971, for example, Baraka proposed building Kawaida Towers, a 16-story affordable apartment building in Newark's North Ward with the support of poor Black residents (Temple of KawaidaChronology of Kawaida Towers, 1973). However, with fierce resistance from white residents of the North Ward, like Anthony Imperiale (Sullivan, 1972), and almost no assistance or acknowledgment from Mayor Gibson, the project was scrapped by 1976 (Sullivan, 1976). 
The Gateway project signaled a new era of corporate influence in city planning that would greatly diminish the role of grassroots organizers. Gibson's largely Black supporters confronted the new reality that "increased black administrative control [did] not mean real power or benefits to the working class because the state and corporate interests retained control over the purse strings of Newark" (Mikell, 1987, p. 88). Additionally, with Black Power activists, much like their predecessors in the 1950s and 1960s, subject to intense, racist federal, police, and military surveillance, torture, and detention well into the 1980s and 1990s under COINTELPRO, the overall prospect of future Black Power leadership or organizing became even slimmer (Haas, 2019).

\section{Conclusion}

White flight to the suburbs between 1960 and 1970, deindustrialization, and the war on drugs that ushered in the 1970s under President Nixon were some of the significant political and economic changes that made it challenging to address marginalization and Black participation in urban planning policy after 1970. The legacy of riots, stigma, and racial bias continued to pervade majority Black neighborhoods creating a silo effect in cities like Newark, Los Angeles, Detroit and Washington DC, which struggled to attract the same goods and services that wealthier, white neighborhoods did.

More than fifty years after the Kerner Report and the Model Cities program, welfare retrenchment and declining support for federal spending on redistributive social policies in the U.S. has led to public outcry on the persistent decline of Black neighborhoods and racial disparities (Brazil, 2016; Bullock, 2020; Casey \& Hardy, 2018). Illustrating the consequences of welfare retrenchment, Chetty, Hendren, Jones, and Porter (2020) have argued that "place" still matters when determining the causes of racial and income disparities in intergenerational outcomes in Black and white neighborhoods. Neighborhoods with low poverty rates, better school quality and low crime rates can help reduce the black-white income gap; however, only $4.2 \%$ of Black children grow up in low poverty neighborhoods (Chetty et al., 2020). Critical sociological research from The Privileged Poor (2019) further clarified that for the majority of Black children who do grow up in under-resourced high poverty areas, these same children end up "doubly disadvantaged" if they make it to college: Black "children from lower-income families... are regarded as having been scarred by poverty" and often struggle adjusting to socioeconomic norms within elite higher education settings (Jack, 2019, p. 19).

Civil rights era legislation passed under the Johnson administration in the 1960s and Black Power pressure politics drew attention to the need for Black solidarity, ethical rules on party patronage, fair housing, and better schools in Black neighborhoods. The visibility of political protest rooted in Black Power ideologies on the electoral stage, as the outcome of earlier efforts by organizers from SNCC, CORE and SDS/ERAP, also started important debates on community control and Black activism that continued into the $21^{\text {st }}$ century. Black resistance to the initial NJCMD construction plans however, also revealed that building back institutional memory around racial justice and activism - that could outlast the remaining vestiges of structural racism in city planning, which dated back to the early twentieth century - was timeconsuming, costly, and complicated by constantly evolving actors and institutions. The NJCMD protests and Newark Agreements remain successful models of grassroots activism and ethnic coalition building - surviving Resurrection City, the Model Cities program, the Kerner Report and the start of welfare retrenchment in the 1970s - because key municipal, grassroots, and federal stakeholders reached a consensus that Black participation was vital in the sustainable development of America's cities. The Newark Agreements were a first attempt at quantifying and qualifying Black participation in the urban renewal process. 
In the aftermath of Resurrection City's forced closing in June 1968, Reverend Ralph Abernathy made a bold promise. From his jail cell, he declared, "Resurrection Cities will spring up all over the country" ("Poverty: Balance on Resurrection City," 1968) — and in many ways he was right. Johnson's War on Poverty throughout the major political and social upheavals of the 1960s encouraged a new era of cooperative judicial federalism, where the federal government did not shy away from asserting its authority over state legislatures to combat the dysfunctionality and decay of America's cities stemming from the rise of identity politics and patronage. Breaking away from Traditionalist models of citizenship and good governance in the U.S. between the 1920s and 1940s (Ahmad, 2016), cooperative judicial federalism also set the foundation for a shift to empowered participation and deliberative democracies in American cities (Esterling, Fung, \& Lee, 2019).

Deliberative democracy and minipublics, where small groups use deliberative polling and ballot measures to influence public policies, have created spaces for ethnic minorities, young people and other underrepresented individuals to become involved in policymaking (Ingham \& Levin, 2018; Strickler, 2017) Do these minipublics ultimately reflect descriptive representation or a distortion of citizen participation, and how do minipublics impact ethnic coalition building? If Black resistance to NJCMD imparts a single lesson, it is that what frequently constitutes equitable participation, social policy, and social disorder, is determined by intra and inter-ethnic group conflicts over access to resources and territory that result in new elected leadership that is not necessarily representative leadership.

\section{Funding Details}

This work was supported by the History Department and Libraries of Harvard College.

\section{References}

Abernathy, R. (1989). And the walls came tumbling down: An autobiography. Harper \& Row. Addonizio, H. (1967). Model Cities Report. Rep. City Hall. Newark, NJ.

Ahmad, I. (2016). The Early Years of American Political Science: Traditionalist Paradigm and its Critics. Research in Social Sciences and Technology, 1(2). doi:10.46303/ressat.01.02.3

Arsenault, R. (2005). Freedom Riders 1961 and the struggle for racial justice. Oxford University Press.

Benford, R. D., \& Snow, D. A. (2000). Framing processes and social movements: An overview and assessment. Annual Review of Sociology, 26(1), 611-639. https://doi.org/10.1146/annurev.soc.26.1.611

Brazil, N. (2016). Large-scale urban riots and residential segregation: A case study of the 1960s U.S. Riots. Demography, 53(2), 567-595. doi:10.1007/s13524-016-0459-9

Bullock, J. (2020). Education and attitudes toward redistribution in the United States. British Journal of Political Science, 1-21. https://doi.org/10.1017/S0007123419000504

Carmichael, S., \&. Hamilton, C. V. (1967). Black power: The politics of liberation in America. Random House.

Casciano, R. (2009). 'By any means necessary': The American welfare state and machine politics in Newark's north ward. [Doctoral dissertation, Princeton University].

Casey, M., \& Hardy, B. (2018). The evolution of Black neighborhoods since Kerner. RSF: The Russell Sage Foundation Journal of the Social Sciences, 4(6), 185-205. https://doi.org/10.7758/rsf.2018.4.6.09

Castells, M. (1983). The city and the grassroots: A cross-cultural theory of urban social movements. University of California Press. 
Chetty, R., Hendren, N., Jones, M., \& Porter, S. (2020). Race and economic opportunity in the United States: An intergenerational perspective. The Quarterly Journal of Economics, 135(2), 711-783. https://doi.org/10.1093/qje/qjz042

Clark, K. B. (1965). Dark ghetto: Dilemmas of social power (1st ed.). Harper \& Row.

Congressional Declaration of National Housing Policy, 42 U.S. Code $\S 1441$ (1949). http://www.law.cornell.edu/uscode/html/uscode42/usc_sec_42_00001441----000notes.html

Cruden, J. (2016). Cooperative federalism in action: ENRD and states. US DOJ Archives: Environment and Natural Resources Division. https://www.justice.gov/archives/opa/blog/cooperative-federalism-action-enrd-andstates

Cunningham, J. T., \& Hill, H. (1988). Newark. New Jersey Historical Society.

DeCaro, D. A., Chaffin, B. C., Schlager, E., Garmestani, A. S., \& Ruhl, J. B. (2017). Legal and institutional foundations of adaptive environmental governance. Ecology and Society, 22(1). https://doi.org/10.5751/es-09036-220132

Dolan, T. (n.d.). Newark and its gateway complex. https://web.archive.org/web/ 20150909230145/http://www.newarkmetro.rutgers.edu/reports/display.php?id=17\&pa ge $=3$

Esterling, K. M., Fung, A., \& Lee, T. (2019). When deliberation produces persuasion rather than polarization: Measuring and modeling small group dynamics in a field experiment. British Journal of Political Science, 1-19. https://doi.org/10.1017/s0007123419000243

Farley, R. (2018). Detroit fifty years after the Kerner report: What has changed, what has not, and why? RSF: The Russell Sage Foundation Journal of the Social Sciences, 4(6), 206. https://doi.org/10.7758/rsf.2018.4.6.10

Gates, Jr., H. (2019). Stony the road: Reconstruction, White supremacy, and the rise of Jim Crow. Penguin Press.

Gelb, J. (1974). Black power in electoral politics: A case study \& comparative analysis. Polity, 6(4), 500-527. https://doi.org/10.2307/3234030

Gibson Civic Association. (1970, June 16). Newark has another chance June $16^{\text {th }}$ don't waste it vote Ken Gibson [Poster Advertisement].

Gibson, K. A. (1978). A case for equity in federal-local relations in urban policy development. Annals of the American Academy of Political and Social Science, 439(1), 135-146. https://doi.org/10.1177/000271627843900110

Gooden, S., \& Myers, S. (2018). The Kerner commission report fifty years later: Revisiting the American dream. RSF: The Russell Sage Foundation Journal of the Social Sciences, 4(6), 1-17. https://doi.org/10.7758/rsf.2018.4.6.01

Greve, M. (2020). Why we need federal administrative courts. SSRN Electronic Journal. https://doi.org/10.2139/ssrn.3561135

Haas, J. (2019). The assassination of Fred Hampton: How the FBI and the Chicago police murdered a Black Panther. Lawrence Hill Books.

Halbfinger, D. M. (1999, December 28). Anthony Imperiale, 68, Dies - Polarizing force in Newark. New York Times. https:/www.nytimes.com/1999/12/28/nyregion/anthonyimperiale-68-dies-polarizing-force-in-newark.html

Hayden, T. (1967). Rebellion in Newark: Official violence and ghetto response. Random House.

Hofferth, S. L., \& Goldscheider, F. (2010). Family structure and the transition to early parenthood. Demography, 47(2), 415-437. https://doi.org/10.1353/dem.0.0102 
Honig, M. (1963, July 3). Racial Job Clash Erupts in Jersey. New York Times. https://www.nytimes.com/1963/07/04/archives/racial-job-clash-erupts-in-jerseynewark-police-workers-and-pickets.html

Iceland, J., \& Hernandez, E. (2017). Understanding trends in concentrated poverty: 1980-2014. Social Science Research, 62, 75-95. https://doi.org/10.1016/j.ssresearch.2016.09.001

Ingham, S., \& Levin, I. (2018). Can deliberative minipublics influence public opinion? Theory and experimental evidence. Political Research Quarterly, 71(3), 654-667. https://doi.org/10.1177/1065912918755508

Jack, A. A. (2019). The privileged poor: How elite colleges are failing disadvantaged students. Harvard University Press.

Jackson, T. (2007). From civil rights to human rights: Martin Luther King and the struggle for economic justice. University of Pennsylvania Press.

Ken Gibson with Supporters. (1970). Newark Public Library.

Lituchy, S. (Director). (2007b, July 14). Interview of Junius Williams on the UMDNJ Fight [VIDEO]. Newark Star-Ledger. https://www.nj.com/ledgernewark/2007/07/junius_williams_the_umdnj_figh.html

Malcolm X: From Nation of Islam to Black Power Movement. (2018, February 21). Al Jazeera News. https://www.aljazeera.com/news/2018/02/malcolm-nation-islam-black-powermovement-180221085553908.html

Massey, D. S., \& Denton, N. A. (1993). American apartheid: Segregation and the making of the underclass. Harvard University Press.

Meier, A. (1973). Black experience: The transformation of activism. Transaction Books.

Mikell, G. (1987). Class and ethnic political relations in Newark. In L. Mullings (Ed.), Cities of the United States: Studies in urban anthropology (pp. 71-98). Columbia University Press.

Mumford, K. (2007). Newark: A history of race, rights, and riots in America. New York University Press.

Newark Agreements. (1968). Rep. Newark, NJ.

NPR: National Public Radio. (2006, January 12). Get on the bus: The Freedom Riders of 1961. http://www.npr.org/templates/story/story.php?storyId=5149667

Poverty: Balance on Resurrection City. (1968, July 5). TIME. http://content.time.com/time/magazine/article/0,9171,941600,00.html

Putnam, R. (2001). Making democracy work: Civic traditions in modern Italy. Princeton University Press.

Rabig, J. (2007). Broken deal: Devolution, development, and civil society in Newark, New Jersey, 1960-1990 [Doctoral dissertation, The University of Pennsylvania].

Schlichting, K., Tuckel, P., \& Maisel, R. (2015). Great migration of African Americans to Hartford, Connecticut, 1910-1930: A GIS analysis at the neighborhood and street level. Social Science History, 39(2), 287-310. https://doi.org/10.1017/ssh.2015.54

Strickler, R. (2017). Deliberate with the enemy? Polarization, social identity, and attitudes toward disagreement. Political Research Quarterly, 71(1), 3-18. https://doi.org/10.1177/1065912917721371

Sullivan, J. (1972, December 5). Kawaida Towers' confrontation in the North Ward of Newark. New York Times. https://www.nytimes.com/1972/12/05/archives/kawaida-towersconfrontation-in-the-north-ward-of-newark.html

Sullivan, J. (1976, July 16). Kawaida Towers given a quiet burial. New York Times. https://www.nytimes.com/1976/07/16/archives/kawaida-towers-given-a-quiet-burialproject-foundation-is-being.html

Teaford, J. C. (1986). The twentieth-century American city: Problem, promise, and reality. Johns Hopkins University Press. 
Temple of Kawaida-Chronology of Kawaida Towers. (1973). The Black Power Movement, pt. 1 (microform). Newark Public Library.

Thompson, J. P. (2006). Double trouble: Black mayors, Black communities, and the call for a deep democracy. Oxford University Press.

Tibaldo-Bongiorno, M. (Director, Producer). (2007). Revolution '67. [FILM]. IVTS and POV.

Trotter, Jr., J. (2002). The great migration. OAH Magazine of History, 17(1), 31-33. https://doi.org/10.1093/maghis/17.1.31

Truman, H. S. (1949, January 5). Annual message to the congress on the state of the union. Harry S. Truman Library Museum. https://www.trumanlibrary.gov/library/publicpapers/2/annual-message-congress-state-union-0

Tuttle, B. R. (2009). How Newark became Newark: The rise, fall, and rebirth of an American city. Rutgers University Press.

Watts, J. G. (2001). Amiri Baraka: The politics and art of a Black intellectual. New York University Press.

Williams, J. W. (1968). Advocacy in Newark: The medical school controversy [Law school thesis, Yale Law School].

Williams, J. W. (2014). Unfinished Agenda: Urban politics in the era of Black Power. United States: North Atlantic Books.

Wilson, W. J. (2012). The truly disadvantaged: The inner city, the underclass, and public policy (2nd ed.). University of Chicago Press.

Workers, Pickets Clash at Barringer Project. (1963). Newark Evening News (microform).

\section{Notes on Contributors}

Edad Mercier is a doctoral research fellow in World History at St. John's University, College of Arts and Sciences in New York City. She graduated with her B.A. in History, Harvard College; MSc in Urbanization and Development Geography, London School of Economics and Political Science; and LL.M. in International Law, Paris Descartes University. Edad has worked as a teacher and artist in France, China, Haiti, Tanzania, and the U.S. From 2015 to 2017, Edad was a lecturer at Paris Dauphine University and University of Orléans in the humanities. Her research interests include law and society, sociocultural anthropology, and international conflicts. 